\title{
Comparison between two surgical techniques for prenatal correction of meningomyelocele in sheep
}

\author{
Comparação entre duas técnicas cirúrgicas de \\ correção intrauterina da mielomeningocele em fetos de ovelha
}

\author{
Silvia Rejane Fontoura Herrera ${ }^{1}$, Ricardo José de Almeida Leme ${ }^{1}$, Paulo Roberto Valente ${ }^{2}$, \\ Élia Garcia Caldini ${ }^{1}$, Paulo Hilário Nascimento Saldiva ${ }^{1}$, Denise Araujo Lapa Pedreira ${ }^{1}$
}

\begin{abstract}
Objective: To compare the classical neurosurgical technique with a new simplified technique for prenatal repair of a myelomeningocelelike defect in sheep. Methods: A myelomeningocele-like defect (laminectomy and dural excision) was created in the lumbar region on day 90 of gestation in 9 pregnant sheep. Correction technique was randomized. In Group 1 the defect was corrected using the classic neurosurgical technique of three-layer suture (dura mater, muscle and skin closure) performed by a neurosurgeon. In Group 2, a fetal medicine specialist used a biosynthetic cellulose patch to protect the spinal cord and only the skin was sutured above it. Near term (day 132 of gestation) fetuses were sacrificed for pathological analysis. Results: There were two miscarriages and one maternal death. In total, six cases were available for pathological analysis, three in each group. In Group 1, there were adherence of the spinal cord to the scar (meningo-neural adhesion) and spinal cord architecture loss with posterior funiculus destruction and no visualization of grey matter. In Group 2, we observed in all cases formation of a neo-dura mater, separating the nervous tissue from adjacent muscles, and preserving the posterior funiculus and grey matter. Conclusion: The new simplified technique was better than the classic neurosurgical technique. It preserved the nervous tissue and prevented the adherence of the spinal cord to the scar. This suggests the current technique used for the correction of spina bifida in humans may need to be reassessed.
\end{abstract}

Keywords: Myelomeningocele; Spinal dysraphism; Fetal therapies; Fetoscopy; Sheep

\section{RESUMO}

Objetivo: Comparar a técnica neurocirúrgica clássica a uma nova técnica simplificada, para correção de mielomeningocele, em fetos de ovelhas. Métodos: Em 9 fetos, foi criado um defeito semelhante à mielomeningocele (laminectomia e excisão de dura-máter) no $90^{\circ}$ dia de gestação. 0 tipo de correção foi randomizado. No Grupo 1, 0 defeito foi corrigido usando a técnica neurocirúrgica clássica, com a sutura de três camadas (dura-máter, músculo e pele), realizada por um neurocirurgião. No Grupo 2, um especialista em Medicina Fetal utilizou a técnica simplificada, colocando um fragmento de celulose biossintética sobre a medula e suturando apenas da pele sobre a celulose. Próximo ao termo da gestação (132 dias), os fetos foram sacrificados para análise anatomopatológica. Resultados: 0correram dois casos de aborto e uma morte materna, restando seis casos para avaliação - três em cada grupo. No Grupo 1, todos os casos mostraram aderência da medula à cicatriz (meningoadesão) e perda da arquitetura medular, com destruição do funículo posterior e perda da visualização da substância cinzenta. No Grupo 2, observou-se, em todos os casos, a formação de uma neodura-máter, separando o tecido nervoso do músculo adjacente, sendo que o funículo posterior e a substância cinzenta estavam preservados. Conclusão: A técnica simplificada foi superior à neurocirúrgica, com maior preservação da medula e evitando as aderências do tecido nervoso. Os presentes achados sugerem que a técnica utilizada atualmente na correção de mielomeningocele em fetos humanos deva ser reavaliada.

Descritores: Meningomielocele; Disrafismo espinal; Terapias fetais; Fetoscopia; Ovinos

\section{INTRODUCTION}

Meningomyelocele is a defect of the primary neurulation, which results from failure of fusing the caudal neural tube ${ }^{(1)}$. It is one of the most common malformations in human fetuses, and may have devastating consequences, such as paraplegia, urinary and intestinal dysfunctions,

Study carried out at Universidade de São Paulo - USP, São Paulo (SP), Brazil; Instituto Dante Pazzanese de Cardiologia - São Paulo (SP), Brazil.

1 Universidade de São Paulo - USP, São Paulo (SP), Brazil.

2 Instituto Dante Pazzanese de Cardiologia - São Paulo (SP), Brazil.

Corresponding author: Denise Araujo Lapa Pedreira - Avenida Albert Einstein, 627/701 - Morumbi - Zip code: $05651-901$ - São Paulo(SP), Brazil - Phone: (55 11) 2151- 9205 or (55 11) 2151-9207 E-mail:wdpedreira@uol.com.br

Received on: Jun 30, 2012 - Accepted on: Sep 27, 2012

Conflict of interest: none. 
and orthopedic abnormalities ${ }^{(1)}$, as well as central nervous system changes resulting from type II Arnold Chiari malformation, which is present in more than $75 \%$ of the affected individuals ${ }^{(2)}$.

In Brazil, the prevalence of neural tube defects ranges from 1.3 cases per 1,000 infants born in São José dos Campos (SP) ${ }^{(3)}$, to 5 cases per 1,000 infants born in Recife $(\mathrm{PE})^{(4)}$.

Experimental studies suggest that the spinal cord is progressively damaged during intrauterine life due to the exposure of the normal nervous tissue to mechanic (fetal movement) and chemical (amniotic liquid) aggressions resulting from the lack of closure of posterior structures ${ }^{(5)}$. The recent publication of the results of the randomized clinical trial "Management of Myelomeningocele Study" (MOMS), performed in the United States, showed that intra-uterine correction improves the neurological prognosis outcome of affected newborn infants when comparing prenatal with post-natal correction ${ }^{(6)}$.

However, despite the neurological advantages, maternal and fetal complications were observed. From the maternal perspective, there was thinning to complete dehiscence of the hysterotomy site scar in $35 \%$ of the cases, placenta abruption in $6 \%$, and acute pulmonary edema in $6 \%$ of the cases, among other complications ${ }^{(6)}$.

The development of less invasive surgical techniques may significantly improve the antenatal treatment of the disease. Therefore, our group successfully developed a sonoendoscopic technique using gasless fetoscopy ${ }^{(7)}$ for fetal treatment. However, in order to allow endoscopic approach, the surgical technique to correct the defect itself was simplified. The success of this new simplified technique was previously demonstrated in rabbits ${ }^{(8)}$ and sheep ${ }^{(9)}$.

The classic neurosurgical procedure, which was used for the correction of the defect in the MOMS study, consists in closing the defect in different planes. Firstly, the neural placode and the dural sac are detached from the adjacent skin. The dura mater is then closed, followed by the suture of the fascia and muscle re-approximation. The skin is then closed at the midline of the defect. So far, the postnatal correction technique was merely transferred for prenatal utilization before being tested in a fetal model.

\section{OBJECTIVE}

To compare the pathological findings of the classic neurosurgical technique for prenatal correction of myelomeningocele with those of a simplified technique, using sheep fetuses.

\section{METHODS}

In total, nine pregnant mixed Hampshire Down sheep were used. They were submitted to a period of at least five days of acclimation at the Experimental Surgery Laboratory of the Instituto Dante Pazzanese de Cardiologia.

Sheep were fasted before the surgery for 48 hours for solids and 24 hours for liquids. Preanesthetic medication included $1 \%$ acepromazine $(0.2$ to $0.4 \mathrm{mg}$ ) $\mathrm{kg})$ and midazolan $(0.3$ to $0.5 \mathrm{mg} / \mathrm{kg})$ by intravenous route (IV). Anesthesia was induced by $2.5 \%$ thiopental (7.5 to $10 \mathrm{mg} / \mathrm{kg}$ ), and maintened with sevoflurane. Cefazolin $1 \mathrm{~g}$ IV was administered in a single dose at the beginning of the surgical procedure as antibiotic prophylaxis.

\section{Creating the defect}

The surgical procedure was performed between 90 and 93 days of gestation. The same surgeon created all the defects, and was not aware of the procedures that would be employed for their correction.

A left para-mammary maternal laparotomy was performed, followed by hysterotomy and removal of $120 \mathrm{ml}$ of amniotic liquid (reserved).

After the exposure of the fetal back, a $3.0 \times 2.0 \mathrm{~cm}$ skin section was excised. Paravertebral muscles were bilaterally removed to perform laminectomy that included three lumbar vertebrae. After the exposure of the spinal canal, a $1.0 \mathrm{~cm}$ excision of the dura mater was performed, exposing the spinal cord. Cerebrospinal fluid (CSF) outflow was observed (Figure 1), and no other spinal cord lesion was performed.

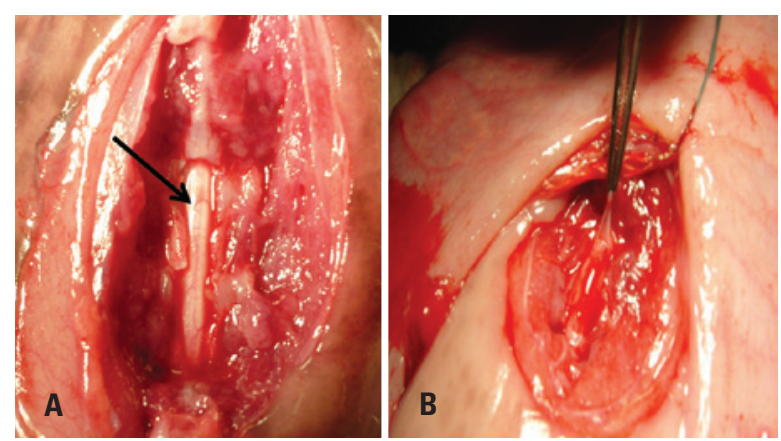

Figure 1. Induced meningomyelocle defect on the 90th gestational day. (A) The arrow shows the exposure of the spinal canal with a fully preserved dura mater (B) The pair of tweezers expose the dura mater that was cut by the scissors leaving an exposed medulla

\section{Defect correction}

Immediately after the defect was created, two kind of surgical correction procedures were performed. The 
technique was selected by simple randomization, with groups of equal sizes, using the statistical program $\mathrm{R}$ 2.11.0 for Windows.

In Group 1, the classic neurosurgical technique was performed, always by the same neurosurgeon, who closed the dura mater using continuous suture with Prolene ${ }^{\circledR}$ 6.0. Muscles were then approximated using Ethibond $^{\circledR} 5.0$ with separate stitches. The skin was closed by continuous suture, using Quill ${ }^{\circledR} 2.0$, a grooved polypropylene suture, which allows its locking, not requiring knots at each ends (Figure 2).

In Group 2, the simplified technique was applied. It consists in placing a $2.0 \times 1.0 \mathrm{~cm}$ biosynthetic cellulose patch (Bionext, Bionext ${ }^{\circledR}$, Brazil) over the spinal cord, with no fixation stitches to the adjacent tissues. Skin was then sutured using the same suture described for Group 1 (Figure 2).

After correction, the fetus was reinserted into the uterus and the reserved amniotic fluid was replaced in the amniotic cavity at the end of the hysterorrhaphy. The maternal abdomen was closed, and the awaken animal was transported to its pen.

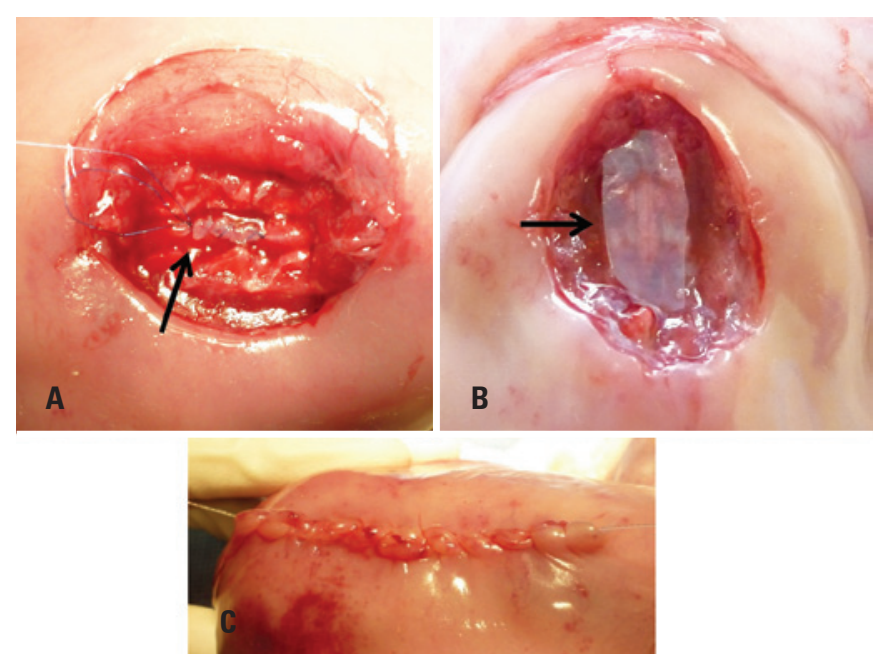

Figure 2. (A) Correction of the defect by means of neurosurgical technique. The arrow shows the dura mater using continuous suture. (B) Correction of the defect by a simplified technique. The arrow shows the biosynthetic cellulose over the medulla. (C) The skin was closed by continuous suture

\section{Sacrifice}

Maternal-fetal sacrifice was carried out on 132 days of gestation. Animals received the same preanesthetic and anesthetic medications, and then a $\mathrm{KCl}$ bolus injection. When maternal and fetal heartbeats stopped, fetuses were removed by laparotomy, weighed, photographed, and submitted to pathological examination of the operated region.

\section{Pathological examination}

A fragment of the operated region, with margins of two spinous processes above and below the lesion, was removed. The specimen remained in formaldehyde for 7 days and were decalcified with EDTA for 40 days. Specimen blocks were then cut in $0.5 \mathrm{~cm}$ sections, and mounted on slides stained with hematoxylin-eosin (HE).

The study was approved by the Ethics Committee of Instituto Dante Pazzanese and by the Ethics Commission of Hospital das Clínicas da Faculdade de Medicina da Universidade de São Paulo.

\section{RESULTS}

In total, 9 sheep were operated. One sheep with twin gestation died on postoperative day $2^{\text {nd }}$, possibly due to bacterial contamination at the time of surgery. Among the 8 remaining animals, 2 had early spontaneous premature delivery 8 and 9 days after surgery. These three cases were excluded from pathological examination. Among the six remaining animals, 3 were sacrificed near term, between 130 and 133 days of gestation. Mean intrauterine stay was 36 days (Table 1).

Among the six animals available for pathological examination, three belonged to Group 1 and three to Group 2. All animals in Group 1 had spontaneous premature delivery, and all those in Group 2 reached the gestational age proposed for sacrifice.

Table 1. Outcome of fetal surgery cases using classic or simplified neurosurgical procedures

\begin{tabular}{lccccccc}
\hline Case & $\begin{array}{c}\text { GASu } \\
\text { (days) }\end{array}$ & $\begin{array}{c}\text { GASs } \\
\text { (days) }\end{array}$ & $\begin{array}{c}\text { IGP } \\
\text { (days) }\end{array}$ & $\begin{array}{c}\text { Fetal } \\
\text { weight } \\
\text { (g) }\end{array}$ & $\begin{array}{c}\text { IUP } \\
\text { (days) }\end{array}$ & $\begin{array}{c}\text { Correction } \\
\text { procedure }\end{array}$ & Follow-up \\
\hline 1 & 95 & 133 & & 3.565 & 38 & Simplified & Sacrifice \\
2 & 90 & 130 & & 4.290 & 40 & Simplified & Sacrifice \\
3 & 90 & & 128 & 1.360 & 38 & Neurosurgery & $\mathrm{PL}$ \\
4 & 91 & & 115 & 2.265 & 24 & Neurosurgery & $\mathrm{PL}$ \\
5 & 91 & 132 & & 2.170 & 41 & Simplified & Sacrifice \\
6 & 92 & & 128 & 1.125 & 36 & Neurosurgery & $\mathrm{PL}$ \\
\hline Mean & 92 & 132 & 124 & 2.462 & 36 & & \\
\hline
\end{tabular}

GASu: gestational age at surgery; GASa: gestational age at sacrifice; GAD: gestational age at delivery; IUP: intrauterine period; PL: premature labor.

Five out of nine cases had spontaneous premature delivery, which led to the investigation of a possible infectious cause of this outcome. Sera of all animals were tested for toxoplasmosis, brucellosis, and leptospirosis. The two fetuses born immediately after surgery were submitted to gross examination, but no conclusive results were found. Fetal tissues were also tested for 
the above-mentioned infectious agents by polymerase chain reaction (PCR), and the results were negative.

\section{Macroscopic examination}

Skin was completely closed in both groups, and no CSF leakage was observed.

\section{Microscopic examination}

\section{Group 1 (neurosurgical technique)}

In all cases of neurosurgical correction, there was strong adhesion of the medulla to the meninges and to the scar tissue that involved the muscle and the skin. A "herniation" of the nervous tissue towards the dura suture site (Figure 3) was observed. In every case, medulla (spinal cord) architecture was lost, with destruction of the posterior funiculus and no visualization of gray matter.

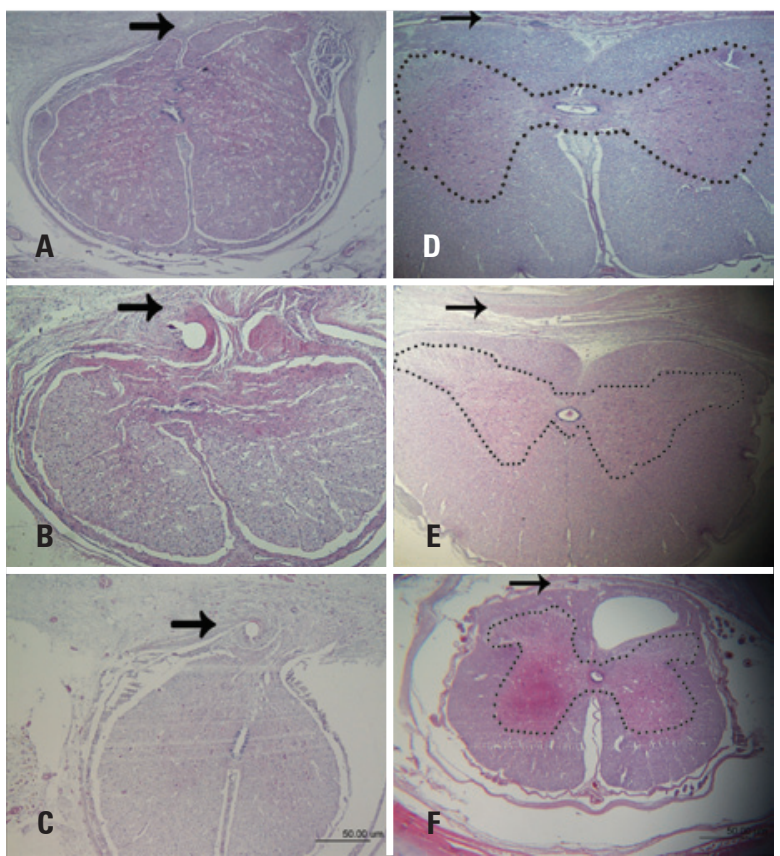

Figure 3. Group 1 - Neurosurgery: (A-C) The thick arrows show the adherence of the medullar tissue to the scar (menyngeal adhesion). Group 2 - Simplified technique using the biosynthetic cellulose: (D-F) The thin arrows show the separation of the muscular tissue by the neodura mater. The images show the preservation of the medullar architecture and the dashed line limits the grey substance

\section{Group 2 (simplified technique)}

In all cases of simplified correction, a fibroblast layer was observed surrounding the cellulose film, maintaining anatomic continuity with the original dura mater, consisting of a neo-dura mater. This tissue and cellulose itself separated the nervous tissue from the scar that involved the muscle and the skin. In this group, the posterior funiculus and the grey matter were preserved (Figures 3 and 4).
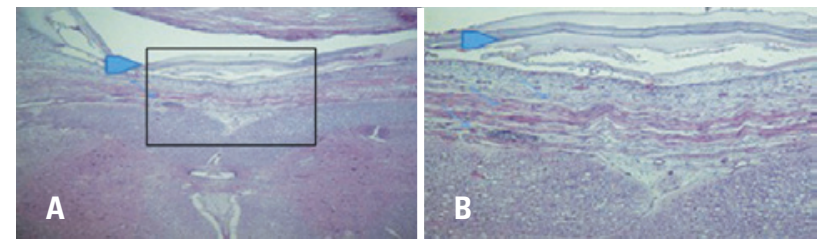

Figure 4. Medullar anatomopathological image (hematoxylin-eosin); the simplified technique was used for the correction of the defect (Group 2), the cellulose can be observed (arrow head) as well as the neodura mater (thin arrow). On image A one can observe at 40x magnification the medullar separation and the absence of adhesion tissue

\section{DISCUSSION}

In the present study, sheep fetuses were used as animal model for the comparison of two techniques of prenatal correction of myelomeningocele, it was observed that the classic neurosurgical technique resulted in an important disrupture of the cytoarchitecture of the spinal cord, with adhesion among the medulla, the meninges, and the skin scar. On the other hand, the simplified correction technique, using cellulose as interface, induced the formation of a neo-dura mater that "isolated" medulla, preventing its adhesion to the meninges and adjacent tissues. The simplified technique also allowed better preservation of the spinal cord cytoarchitecture.

Several previous studies on the intrauterine correction of myelomeningocele had already suggested that prenatal correction led to a better preservation of the spinal cord and better clinical results ${ }^{(10-13)}$.The MOMS study demonstrated that the intrauterine correction reduced the need of ventriculoperitoneal shunting from 82 to $40 \%$ comparing postnatal with prenatal correction, respectively. That study also showed better cognitive and motor skills up to 30 months of age in the group submitted to prenatal correction ${ }^{(6)}$.

As to the uterine approach, some studies showed that open surgery greatly increased the risk of premature labor and maternal complications ${ }^{(6,10,12)}$. In the MOMS study, average gestational age at birth was 34.1 weeks in cases of prenatal surgery versus 37.3 weeks in postnatal surgery. In addition, the difference in the number of spontaneous membrane rupture was significant, with $46 \%$ of the cases of open surgery versus $8 \%$ of postnatal surgery cases ${ }^{(6)}$.

Maternal morbidity associated with open correction suggests that minimally invasive methods are the future of antenatal correction of myelomeningocele. Some authors have studied the endoscopic correction of this defect both in animal models ${ }^{(14-16)}$ and in humans ${ }^{(17)}-$ in 
the later, results are still incipient, but promising. We believe that a successful correction of myelomeningocele by fetoscopy requires the development of a simplified closure technique of the defect itself, as the classic neurosurgical technique includes suturing the dura, re-approximation of the muscles, and skin closure in different planes. The classic closure not only would be technically difficult to perform by fetoscopy, but also would significantly increase surgery time, which is considered important for the success of endoscopic procedures.

Aiming at simplifying myelomeningocele closure, several materials have been tested to replace the dura mater in animal models. Also, the use of glues, sealants, and different sutures have been reported ${ }^{(14,18,19)}$.

Biosynthetic cellulose was tested as dura mater substitute in dogs submitted to craniotomy by Mello et al. ${ }^{(18)}$, and it was found that it induced the formation of neo-dura mater. Our group tested cellulose for the correction of a spinal defect in rabbit fetuses ${ }^{(8)}$, and later in sheep fetuses ${ }^{(9,20)}$, and showed that this material did not cause foreign-body reactions and that it also led to the formation of a neo-dura mater, preventing adhesion between the scar and the medulla. In these studies the cellulose was placed over the medulla, and no stitches or adhesive substances were used for fixation; only the skin was closed over the cellulose patch to maintain it over the medulla.

One of the limitations of the present study was the lesion created here is different from the myelomeningocele observed in human fetuses. The created lesion was immediately corrected and the medulla was not chronically exposed to the amniotic fluid. Only the dura mater was removed, and no intentional lesion was caused to the spinal cord. Because the objective of this study was to compare the effect of different correction techniques on the spinal cord, it was important that the same type of defect was corrected in order to ensure lesion reproducibility. It was assumed that it would be difficult to reproduce spinal cord lesions, and therefore, we chose to cause lesion just to the dura mater, which we believe it is easier to reproduce. Considering the obtained results, this aspect may have favored the comparison: the correction was performed on an intact medulla - only the dura mater was removed, suggesting that the neurosurgical procedure per se may "induce" the disruption of the spinal cord cytoarchitecture. Further studies are required to evaluate the causes of this derangement as well as if it may worsen a pre-established lesion, possibly aggravating the neurological outcome.
The present study showed that the simplified technique produced better results; however, it would be interesting to evaluate if this preservation of the cytoarchitecture translates into better neuropsychomotor development. In addition, its effect on the posterior fossa should also be assessed to determine if the simplified technique is able to return the cerebellum to its original position, reversing cerebellar herniation. Theoretically, neuronal preservation in the anatomic level should result in a better neuropsychomotor development, with less longterm neurological sequelae.

Another limitation of this study was the low number of cases available for comparison. However, differences between groups were so significant in all aspects evaluated, that the need to increase the number of cases is questioned. Because all cases in Group 1 presented meningoneural adhesion, whereas this was absent in all cases in Group 2, where the presence of neo-dura mater was observed.

One of strengths of this study is related to the so-called tethered cord. Adhesion of the spinal cord to the scar tissue is observed by imaging techniques in all cases of post-natal correction using the classic procedure in humans ${ }^{(21)}$. But, only some newborns will present the clinical manifestations called tethered spinal cord syndrome (TSCS). The symptoms associated to this syndrome are progressive neuronal deterioration, seizures, neurogenic bladder, fecal incontinence, and severe scoliosis ${ }^{(22,23)}$. In these cases, the defect must be reoperated to "free" the spinal cord, which eventually worsens the neurological prognosis. When the simplified technique was performed, no adhesion of the medulla to the skin scar was observed, which may potentially prevent TSCS development in newborn infants.

Concerning tethered spinal cord, there are few studies published ${ }^{(6,21,24)}$ comparing the outcome of human fetuses operated before and after birth. Danzer et al. reported a significant difference in the postnatal outcome of fetuses submitted to intrauterine correction compared with those corrected after birth. In the prenatal correction group, in cases that developed TSCS and required surgery, the tethered cord was associated with dermoid cysts in $63 \%$ of the cases, whereas in the cases of postnatal correction, this association was observed only in $25 \%$ of the cases ${ }^{(21)}$. The study was not randomized and none of the hypotheses raised to explain this difference was acceptable, according to the authors. The two most recent studies ${ }^{(6,24)}$ showed higher TSCS incidence in fetuses operated before birth. In the MOMS study, there were 6 cases of tethered spinal cord out of the 77 fetuses submitted to intrauterine 
operation, while there was only one case among the 80 cases operated after birth. Verbeek et al. showed five TSCS cases out of 13 fetuses operated in utero and 2 cases among 13 operated after birth ${ }^{(24)}$.

A possible explanation for these findings would be significant differences between fetal and neonatal healing. However, if this was true, these findings would indicate "worse healing" during the fetal period, which is probably not the case, as it is known that the fetus "heals with no scar formation"(25).

Another hypothesis that may explain that difference may be that suturing the dura mater causes the adhesion between the meninges and the nervous tissue. Haines et al., had already demonstrated that the penetration of the needle to suture the dura mater triggers intense inflammatory response, culminating in meningodural adhesion $^{(26)}$. Palm et al., in a study with dogs, showed that the use of nonpenetrating clips for dural closure prevent adhesion between the spinal cord and the meninges, whereas the penetration of the dura mater and the use of different suture threads induced adhesion ${ }^{(27)}$.

In the present study, all cases operated using the neurosurgical technique presented adhesion of the spinal cord to the scar. If this was caused by the inflammatory reaction produced by dural suture, this inflammatory reaction may have also contributed for the structural disruption of the spinal cord at the lesion level. Accordingly, studies on acute spinal cord lesion models show that the suppression of the inflammatory response may reduce neuronal lesions ${ }^{(28)}$.

The results of the present study showed that all cases submitted to neurosurgical correction presented premature labor, whereas all cases of simplified correction reached gestation term. The relation between premature labor and chronic inflammation is well known. It would be interesting to determine if the chronic inflammatory activity caused by the presence of the non-absorbable suture may have contributed to that difference.

A previous study carried out by our group ${ }^{(25)}$, using a skin graft to close a skin defect large enough to not allow its suture, showed that the fetus "found its way" between the two artificial skin layers, and a new epidermis was formed above the dermal matrix. Since this type of regeneration was never demonstrated in adults before, we hypothesized that the excellent fetal healing was responsible for this difference. In the simplified correction group in the present study, the fetuses "found their way" and produced a neo-dura mater in its right place; however, this was not observed in the other group. We believe that this difference may be explained by the presence of the suture material, causing a local chronic inflammation, thereby "misguiding" fetal healing. Consequently not allowing the reestablishment the original tissue planes, which seems to be a natural tendency in the fetus. This would eventually lead to meningodural adhesion.

To date, we found no other studies evaluating the effects of the classic neurosurgical techniques on the medulla during fetal life. This was established in the present study, which also allowed comparing these effects with those obtained with a simplified surgical technique. When open surgery for myelomeningocele repair was performed, there was in fact a mere transference of the same technique used after birth to an intrauterine correction ${ }^{(6)}$. These findings suggest that the classic technique may cause undesirable effects on the fetus when compared with the newborn, and that the higher or earlier incidence of tethered spinal cord may be prevented using the simplified technique.

This leads us to suggest that, if these findings are confirmed by other studies, the surgical technique used for the antenatal correction of myelomeningocele should be changed, even when open surgery is used.

\section{CONCLUSIONS}

The simplified technique was better than the neurosurgical technique because it allowed the preservation of the normal cytoarchitecture of the spinal cord and prevented its adhesion to the scar. The neurosurgical technique per se causes medullar damage and its adhesion to the meninges. The findings of the present study suggest that the classic technique currently applied in the prenatal correction of myelomeningocele in human fetuses should be reviewed.

\section{REFERENCES}

1. Mitchell LE, Adzick NS, Melchionne J, Pasquariello PS, Sutton LN, Whitehead AS. Spina bifida. Lancet. 2004;364(9448):1885-95.

2. Just M, Schwarz M, Ludwig B, Ermert J, Thelen M. Cerebral and spinal MRfindings in patients with postrepair myelomeningocele. Pediatr Radiol. 1990; 20(4):262-6.

3. Nascimento LF, Pinto CO, Proença FP, Gotlieb SL. Prevalência de anomalias congênitas em São José dos Campos, São Paulo, em 2001. Rev Paul Pediatria. 2006;24(1):47-51.

4. Pacheco SS, Souza Al, Vidal SA, Guerra GV, Batista-Filho M, Baptista EV, et al. [Neural tube defects prevalence in newborn infants in the Women Care Center of the Instituto Materno Infantil Prof. Fernando Figueira, IMIP: 2002004]. Rev Bras Saúde Matern Infant. 2006:6(Suppl 1):535-542 . Portuguese.

5. Meuli M, Meuli-Simmen C, Hutchins GM, Seller MJ, Harrison MR, Adzick NS The spinal cord lesion in human fetuses with myelomeningocele: implications for fetal surgery. J Pediatr Surg. 1997;32(3):448-52.

6. Adzick NS, Thom EA, Spong CY, Brock JW 3rd, Burrows PK, Johnson MP, Howell LJ, Farrell JA, Dabrowiak ME, Sutton LN, Gupta N, Tulipan NB, D’Alton $\mathrm{ME}$, Farmer DL; MOMS Investigators. A randomized trial of prenatal versus postnatal repair of myelomeningocele. N Engl J Med. 2011;364(11):993-1004. 
7. Pedreira DA, Oliveira RC, Valente PR, Abou-Jamra RC, Araújo A, Saldiva PH. Gasless fetoscopy: a new approach to endoscopic closure of a lumbar skin defect in fetal sheep. Fetal Diagn Ther. 2008;23(4):293-8.

8. Pedreira DA, Valente PR, Abou-Jamra RC, Pelarigo CL, Silva LM, Goldenberg S. Successful fetal surgery for the repair of a 'myelomeningocele-like' defect created in the fetal rabbit. Fetal Diagn Ther. 2003;18(3):201-6.

9. Abou-Jamra RC, Valente PR, Araújo A, Sanchez e Oliveira RC, Saldiva PH, Pedreira DA. Simplified correction of a meningomyelocele-like defect in the ovine fetus. Acta Cir Bras. 2009;24(3):239-44.

10. Bruner JP, Tulipan N, Paschall RL, Boehm FH, Walsh WF, Silva SR, et al. Fetal surgery for myelomeningocele and the incidence of shunt-dependent hydrocephalus. JAMA. 1999;282(19):1819-25.

11. Meuli M, Meuli-Simmen C, Yingling CD, Hutchins GM, Timmel GB, Harrison $M R$, et al. In utero repair of experimental myelomeningocele saves neurological function at birth. J Pediatr Surg. 1996;31(3):397-402.

12. Tulipan N, Sutton LN, Bruner JP, Cohen BM, Johnson M, Adzick NS. The effect of intrauterine myelomeningocele repair on the incidence of shunt-dependent hydrocephalus. Pediatr Neurosurg. 2003;38(1):27-33.

13. Bouchard S, Davey MG, Rintoul NE, Walsh DS, Rorke LB, Adzick NS. Correction of hindbrain herniation and anatomy of the vermis after in utero repair of myelomeningocele in sheep. J Pediatr Surg. 2003;38(3):451-8; discussion 451-8.

14. Fontecha CG, Peiro JL, Sevilla JJ, Aguirre M, Soldado F, Fresno L, et al. Fetoscopic coverage of experimental myelomeningocele in sheep using a patch with surgical sealant. Eur J Obstet Gynecol Reprod Biol. 2011; 156(2):171-6.

15. Copeland ML, Bruner JP, Richards WO, Sundell HW, Tulipan NB. A model for in utero endoscopic treatment of myelomeningocele. Neurosurgery. 1993; 33(3):542-4.

16. Kohl T, Hartlage MG, Kiehitz D, Westphal M, Buller T, Achenbach $S$, et al. Percutaneous fetoscopic patch coverage of experimental lumbosacral fullthickness skin lesions in sheep. Surg Endosc. 2003;17(8):1218-23.

17. Kohl T, Tchatcheva K, Merz W, Wartenberg HC, Heep A, Muller A, et al. Percutaneous fetoscopic patch closure of human spina bifida aperta: advances in fetal surgical techniques may obviate the need for early postnatal neurosurgical intervention. Surg Endosc. 2009;23(4):890-5.

18. Mello LR, Feltrin LT, Fontes Neto PT, Ferraz FA. Duraplasty with biosynthetic cellulose: an experimental study. J Neurosurg. 1997;86(1):143-50.

19. Eggink AJ, Roelofs LA, Feitz WF, Wijnen RM, Mullaart RA, Grotenhuis JA, et al. In utero repair of an experimental neural tube defect in a chronic sheep model using biomatrices. Fetal Diagn Ther. 2005;20(5):335-40.

20. Sanchez e Oliveira Rde C, Valente PR, Abou-Jamra RC, Araújo A, Saldiva PH, Pedreira DA. Biosynthetic cellulose induces the formation of a neoduramater following pre-natal correction of meningomyelocele in fetal sheep. Acta Cir Bras. 2007;22(3):174-81

21. Danzer E, Adzick NS, Rintoul NE, Zarnow DM, Schwartz ES, Melchionni J, et al. Intradural inclusion cysts following in utero closure of myelomeningocele: clinical implications and follow-up findings. J Neurosurg Pediatr. 2008;2(6): 406-13.

22. George TM, Fagan LH. Adult tethered cord syndrome in patients with postrepair myelomeningocele: an evidence-based outcome study. J Neurosurg. 2005;102(2 Suppl):150-6.

23. Dias MS. Neurosurgical causes of scoliosis in patients with myelomeningocele: an evidence-based literature review. J Neurosurg. 2005;103(1 Suppl):24-35.

24. Verbeek RJ, Heep A, Maurits NM, Cremer R, Hoving EW, Brouwer OF, et al. Fetal endoscopic myelomeningocele closure preserves segmental neurological function. Dev Med Child Neurol. 2012;54(1):15-22.

25. Pedreira DA, Quintero RA, Acácio GL, Espin Garcia Caldini ET, Nascimento Saldiva PH. Neoskin development in the fetus with the use of a three-layer graft: an animal model for in utero closure of large skin defects. J Matern Fetal Neonatal Med. 2011;24(10):1243-8.

26. Haines DE. On the question of a subdural space. Anat Rec. 1991;230(1):3-21.

27. Palm SJ, Kirsch WM, Zhu YH, Peckham N, Kihara S, Anton R, et al. Dural closure with nonpenetrating clips prevents meningoneural adhesions: an experimental study in dogs. Neurosurgery. 1999;45(4):875-81.

28. Leme RJ, Chadi G. Distant microglial and astroglial activation secondary to experimental spinal cord lesion. Arq Neuropsiquiatr. 2001;59(3-A):483-92. 